InOdia $\quad \begin{aligned} & \text { InMedia } \\ & \text { The French Journal of Media Studies }\end{aligned}$

7.2. $\mid 2019$

Documentary and Entertainment

\title{
Rethinking the convergence of documentary and entertainment
}

David Lipson and Zachary Baqué

\section{(2) OpenEdition \\ 12 Journals}

Electronic version

URL: http://journals.openedition.org/inmedia/1601

DOI: 10.4000/inmedia.1601

ISSN: 2259-4728

Publisher

Center for Research on the English-Speaking World (CREW)

Printed version

Date of publication: 15 December 2019

\section{Electronic reference}

David Lipson and Zachary Baqué, "Rethinking the convergence of documentary and entertainment", InMedia [Online], 7.2. | 2019, Online since 20 December 2019, connection on 26 January 2021. URL: http://journals.openedition.org/inmedia/1601 ; DOI: https://doi.org/10.4000/inmedia.1601

This text was automatically generated on 26 January 2021.

(C) InMedia 


\title{
Rethinking the convergence of documentary and entertainment
}

\author{
David Lipson and Zachary Baqué
}

In what is often considered the first serious book-length study of the documentary, at least in English, Paul Rotha describes "the documentary method as the first real attempt to use cinema for purposes more important than entertainment". For Rotha, who was a practicing filmmaker as well as a theoretician and promoter of the documentary, this emerging film form should have higher aspirations than the "repetition of senseless stories" offered by fiction films. It should thus aspire to "surprise". ${ }^{1}$ Despite the author's original intuition that documentaries could provide pleasures, albeit purely intellectual, studying documentary through the prism of entertainment may still seem unusual. After all, a commonsense approach may claim that documentary and entertainment are mutually exclusive, at least semantically. The term "documentary" still evokes boredom linked to overt didacticism, as evidenced by the memories of many a former high school student who had to sit through $\mathrm{PBS}^{2}$ or BBC documentaries in biology or history class. "Entertainment", on the other hand, implies an idea of fun or leisure, something that should not be taken seriously. How, then, can a serious film form such as the documentary ever be considered entertaining? Another way to gauge the opposition between the two notions would be to consider their obvious social functions: while entertainment is thought to be a form of escapism, a necessary departure from the toils of the harsh world around us, a documentary precisely engages us with that same world. Entertainment would, thus, entail a form of political disempowerment, whereas documentaries would encourage, if not create, political commitment. This seeming contradiction between the two terms is due in part to traditional scholarly approaches in analyzing them as well as John Grierson's ${ }^{3}$ influence on documentary film from its early days. 


\section{Documentary vs. Entertainment}

2 In Representing Reality, Bill Nichols' pioneering book, self-described as "the first sustained, theoretical formulations regarding documentary film as a whole" ${ }^{4}$, the author presents documentary film as one of the "discourses of sobriety", which, along with "science, economics, politics, foreign policy, education, religion, welfare", "assume they have instrumental power; they can and should alter the world itself, they can effect action and entail consequences." ${ }^{5}$ Because of this early emphasis on documentary as serious discourse, much documentary scholarship has focused on cognition, knowledge, and ideology. Consequently, there has been a specific focus on the rhetoric of the documentary. For example, Nichols' "documentary voice", his main metaphor to analyze how documentaries speak to us as individual viewers, leads him to describe how this voice convinces and persuades. ${ }^{6}$ Similarly, in the aptly named Rhetoric and Representation in Nonfiction Film, Carl Plantinga aims at providing "a pragmatics and a rhetoric of moving picture nonfictions" (emphasis in original) in order to study "how nonfictions are used to perform various social tasks." "The utilitarian vision of the social function of the documentary is thus best approached and described by the rigor of textual analysis, an effect that John Corner describes as "the inescapably 'cognitive' character of documentary, and its function within the public economy of public knowledge". ${ }^{8}$ This can, partly, be the reason why the rhetorical approach to the documentary and the study of how it produces meaning have been widely used in college classes on the documentary. Stella Bruzzi regrets that it has become "not one way of looking at documentary history and production, but the way."9 (emphasis in original) The pedagogical focus on documentary as education may explain why documentary is still perceived as disconnected from the logics of entertainment.

For Richard Dyer, entertainment has only one function which is "providing pleasure"10 but this is not enough to adequately define entertainment. The idea of entertainment is linked to "the primacy of pleasure" in "artefacts and performances"11, pleasure being the first goal of entertainment, potentially relegating the other goals of these artefacts and performances to mere afterthoughts. It is precisely the link between the primary and other goals of cultural objects that will become the focus of cultural studies. In the 1980s, when academia still had to justify its interest in mass culture, entertainment became virtually synonymous with mass culture. The very title Studies in Entertainment: Critical Approaches to Mass Culture is quite symptomatic of that trend, entertainment being first and foremost what appeals to the masses. In the introduction to the book ${ }^{12}$, Tania Modleski uses "mass culture" and "entertainment" almost interchangeably, conflating an object of study to one of its principles, if not the main one. Her description of the latest (to date) debates in the theories of mass culture could thus be extended to entertainment. For the Frankfurt School, entertainment manipulates the masses and imposes false consciousness, an approach that Dyer mocks because it sees entertainment simply as "a sugar on the pill of ideological messages" ${ }^{13}$ whereas some in the Birmingham School see entertainment as ultimately liberating and empowering in the sense that it allows audiences individually to resist the ideology of the entertaining text. For Modleski, the way out of this methodological conundrum is to find the adequate critical distance, in other words a "critical view [...] that would concentrate on texts without, however, disregarding contexts." ${ }^{14}$ 
If traditional scholarly approaches in analyzing "documentary" and "entertainment" have caused a rift between the two terms, for some, John Grierson is to blame for this disassociation. His vision of what the new film form could do was based on the necessity of government-funded public education to explain the large and complex issues facing the modern world. In this vision, documentary was a way to "counteract Hollywood escapism" 15 and thus entertainment was to be avoided. Mark Cousins and Kevin Macdonald explain his motivations as such: "In fact, his own ideas on what the documentary should and shouldn't be were much more specific and the key to them is a distrust of play-acting and entertainment instilled in him by his Scottish Calvinist upbringing." ${ }^{16}$ The psychological explanation notwithstanding, it is quite certain that Grierson has exerted great influence not only on how and why documentaries are made but also on how they are seen. For Brian Winston, who has consistently and thoroughly criticized him, his legacy is responsible for the public's perception that a documentary "is a virtual guarantee of boredom." ${ }^{17}$ Winston wants to "liberate documentary" from Grierson's exclusive focus on public education in order to create "a documentary form that could be, on occasion, satiric, irreverent and comic," entertaining in a word, a strategy he believes could be "truly popular." ${ }^{18}$ In that sense, if we follow Winston, a documentary does not necessarily have to be boring, since other social functions, beyond mere education, can be envisioned for the form.

5 However, the educational streak and entertainment can fruitfully be combined. In her influential analysis of feminist documentaries, Sonya Michel makes "entertainment" one of "the problems intrinsic to all documentary filmmaking". For her, a documentary is "the translation of factual material into visual form which is both informative and entertaining." ${ }^{19}$ Similarly, if the original impulse of the documentary is representation, then, as Dyer contends, "Representation is a building block of things that are entertaining and the power of much representation resides in its ability to entertain." 20 In a way, both Michel and Dyer suggest that, in order to be efficient and successful in its task to represent and educate, a documentary has to be entertaining.

\section{Documentary and/or entertainment}

6 The fleeting and evolving definitions of "documentary" and "entertainment" as concepts requires that they be historicized. Indeed, the very validity of the term "documentary" was contested in a 2013 manifesto by Peter Wintonick, who rejected "documentary" to offer a new descriptive to an ever-growing practice: "docmedia". ${ }^{21}$ If this knee-jerk reaction against "documentary" and what it connotes is not entirely new, what is new in Wintonick's suggestion is the reaffirmation that dealing with the real need not be constrained by one specific medium. What may have been meant to be a mere provocation, made by a self-described "film-maker" and "docmedia operative", in the last chapter of a collective scholarly book on the documentary, has recently caught on in academic circles as the most adequate way to describe a social practice regardless of the chosen medium. In The Art of Documenting: Documentary Film in the $21^{\text {st }}$ Century, Brian Winston, the editor of the book in which Wintonick's manifesto was originally published, and his coauthors, Gail Vanstone and Wang Chi, contend that a traditional linear documentary film is just but one example of what docmedia can be, as they celebrate the potentialities afforded to the approach by the digital turn.$^{22}$ It is one of our arguments that "documentary", regardless of its obvious limitations as a 
describing term, should be maintained if only as a social and historicized construct. Similarly, Richard Dyer forcefully suggests that "entertainment" is "historically specific". ${ }^{23}$ According to him, since "everything becomes entertainment, entertainment itself ceases to be a category." ${ }^{24}$ Entertainment can remain a category if it is understood through its "experiential component", as a widely used textbook does. ${ }^{25}$ What one experiences as entertainment becomes entertainment. If the experience involves watching a documentary, in the historically specific sense suggested above, then this documentary is entertaining. The more various spectators experience entertainment about the documentary in question, the more popular it will be. This increased popularity would then lead to an evolution of the genre, a possible new "golden age" as the documentary film was perceived to cater to an elite and small audiences, especially in the USA during the middle of the $20^{\text {th }}$ century.

Quite regularly film critics and scholars hail the advent of this new "golden age" of documentaries. Some indicate the late 2010s as the true golden age of documentaries. Basing its main argument on the greater general exposure of documentaries and their greater commercial values, a Huffington Post article ${ }^{26}$ quotes director Morgan Neville claiming that "we're really in a kind of a golden age of documentaries". More recently, a segment of NPR's All Things Considered contends that ours is "an undeniable golden age for documentary filmmaking" 27 , suggesting that previous golden ages were simply false alarms. Whether ours is truly a golden age of documentaries can obviously be criticized: after all the expression was used to qualify other periods in the history of documentaries, from Jack C. Ellis and Betsy McLane claiming that the 1950s and 1960s were the "golden years" of documentary television ${ }^{28}$, to the International Documentary Association which in 2002 argued that the 1990s was the golden age of documentaries. ${ }^{29}$ Yet, on the same website, a strangely undated article claims that the "new golden age of documentary is almost over"! ${ }^{30}$ Finally, Bill Nichols' suggests that "the current Golden Age of documentaries began in the 1980s" and "continues unabated." ${ }^{11}$ Among this pedestrian disagreement as to which decade best represents the golden age of documentaries, Nichols' claim seems to be the most pertinent as documentary filmmaking was starkly transformed in the 1980s due to the emergence of a new trend where entertainment became a key factor. The most visible feature of this trend was when the documentarian took on the role of the star of his own movie. This was seen notably in Sherman's March (Ross McElwee, 1986), Driving Me Crazy (Nick Broomfield, 1988) and Roger \& Me (Michael Moore, 1989). All three films cast the documentary filmmaker in the movie as an actor/host/protagonist leading the audience through the film creating a "double inclusion" effect ${ }^{32}$ where the filmmaker is also the one being filmed. What Nichols refers to as "filmmaker as protagonist" 33 is when the documentarian, through his presence and performance, physically materializes the viewpoint of the spectator and allows them to identify with him/her. Moreover, this format resembles investigative journalism that is familiar to the general audience and thus helps lead the spectator through the narrative. Consequently, by rendering the documentary form more accessible to a general audience, the double inclusion effect also increases the film's capacity to entertain. This is especially the case in Moore's film, which not only dealt with the devasting impact of GM layoffs on the city of Flint via "discourses of sobriety" but combined them with strong narrative and heavy doses of entertainment (humor, popular music, changes in rhythm, juxtapositions, as well as other elements to keep the spectator's attention) propelling his controversial film to the top of the box office. ${ }^{34}$ The film scholar Paul Arthur noted that "For two decades 
prior to the release of Roger \& Me, barely a handful of documentaries per year were shown theatrically in the United States. In 2005, more than 60 docs or roughly 15 percent of total releases, had commercial runs." ${ }^{35}$

8 In 2014, Moore went on to publish "13 Rules for Making Documentary Films". ${ }^{36}$ In this tongue-in-cheek set of rules, the documentary filmmaker's "number one guiding principle" clearly opposes the classical approach of documentarians, which he compares to "Mother Superior with a wooden ruler in [their] hand" or, worse, "Baptist preachers", to his own practice that unapologetically "adher[es] to the tenets of entertainment." In a different context, that of government film propaganda, Fanning Hearon, who was Director of the Division of Motion Pictures in the Department of the Interior when he outlined the beliefs of "those of [them] in the Division", clearly suggested that "entertainment has a place in the educational film." ${ }^{37}$ Hearon does not equate "the educational film" with the documentary film form and Moore openly mocks the didactic value and purpose that some, such as Grierson, ascribe to the documentary. Nevertheless, even today there is still a perception that a documentary is serious and objective and a fiction film is entertaining. When writer Anthony McCarten was criticized for historical inaccuracies in his blockbuster biopic Bohemian Rhapsody (Bryan Singer, 2018). He simply replied "we're making a movie here, not a documentary." ${ }^{38}$ McCarten's argument is that he needed "to move small things around for dramatic impact," ${ }^{39}$ implying that unlike documentary, a fiction film would allow for this fictionalization of reality for the purposes of entertainment. If some practitioners of documentary and fiction films alike so strongly reject the term, it is clearly because it still carries the connotations of boredom and seriousness already mentioned and felt by large parts of the documentary audience.

9 The "expectations of audiences", Nichols contends in his seminal Introduction to Documentary, are some of the "fundamental factors that both uphold a sense of what a documentary is at a given time and place". ${ }^{40}$ This focus on audiences has led to different methodological approaches to analyze what they perceived from and expected of documentaries and how entertainment factored in both. For example, without fully embracing the psychoanalytic model, Michael Renov has consistently tried to free documentary studies from "that position's preference for knowledge effects over pleasurable or ecstatic looking and for its enthronement of sobriety at the expense of the evocative and delirious." ${ }^{41}$ For him, sober realism and truth claims are not the only reasons why audiences find pleasure in documentaries. There is something more, which entertainment may begin to explain, that documentaries studies should strive to evaluate. Within a stricter Lacanian framework influenced by apparatus theory, Elizabeth Cowie shares a similar premise: for her, a documentary "also involves more disreputable features of cinema usually associated with the entertainment film, namely the pleasures and fascination of film as spectacle." ${ }^{42}$ Trying to gauge how these pleasures influence documentary watching, Annette Hill follows the sociological methods of quantitative surveys, focus groups and interviews to highlight multiple modes of engagement with the documentary as "viewers change their mode of engagement depending on their expectations about the documentary they are watching". Her studies have shown that when audiences classify a documentary as entertaining, they do not necessarily consider it to be uninformative, and vice-versa. ${ }^{43}$ Conversely, audiences seem to be much more aware of the inherent ambiguity of documentary forms than theory would have it: as one respondent put it "documentaries are an illusion, but...you don't notice it too much." The evolution of 
documentary forms, such as the ones related to so-called reality television described above, has a direct influence on the expectations of audiences, as explained by Craig Hight. ${ }^{44}$ Moving away from audience expectations to tackle documentary filmic texts, Hight also shows that entertainment and humor in documentaries are not the exclusive purview of recent television documentary hybrids but that they have infused a longer tradition of documentary filmmaking. ${ }^{45}$

\section{Docu-tainment}

Since the beginning of the $21^{\text {st }}$ century, documentary studies have indeed broadened their area of investigation by including new filmic and TV objects that seem to be purely entertaining. When he expanded the scope of documentary studies by including "the new and entertaining forms of tele-factuality" ${ }^{46}$, John Corner also opened up the functions of the documentary: to the traditional functions of propaganda, exposition, and analysis, he added diversion as a key function. ${ }^{47}$ Closely following Corner and expanding on the modes of documentary identified by Bill Nichols, Keith Beattie has even made entertainment a subcategory of documentary by adding "observationentertainment" to the list. ${ }^{48}$ The "observation-entertainment" mode includes different forms, "such as 'reality television', the docusoap, and reality game shows", all subsumed by Beattie under the "popular factual entertainment" category. ${ }^{49}$ What is a social function for Corner has become a classification tool for Beattie, but the analytical impulse is the same, namely that entertainment or diversion is part and parcel of documentary practices and receptions.

11 Even if these new subgenres of the all-encompassing documentary form have goals quite the opposite of Grierson's original intent, in the sense that their informative nature is rather limited to say the least, they nevertheless participate in a general blurring of genres and functions in which "news and documentary are increasingly presented in the same terms as entertainment, using its forms of presentation". ${ }^{50}$ Various neologisms aimed at describing the new hybrid (mostly TV) forms infotainment, edutainment, politainment, docusoaps, gamedocs, etc. - have come and gone out of academic fashion..$^{51} \mathrm{~A}$ recent documentary format has been dubbed the "interactive documentary", including both "non-linear textual structures that must be navigated by the user" and "location-based and crowd-sourced documentaries". Both are described as "playful" and potentially entertaining ways to engage with the political reality as citizens. Whether these new documentary formats allowed by digital technologies will truly create a documentary utopia, freed of the constraints of past practices and traditions remains to be seen..$^{52}$ Nevertheless, in a world where the indexicality of documentary images can be entirely reworked so easily, ${ }^{53}$ thus casting doubt on the veracity of all images, where basic verifiable facts are put into question and referred to as "fake news", and where these elements have direct political consequences on the world (cf. the election of Trump in 2016), it seems necessary to reassess the relation between documentary and entertainment, hence the aim of this issue of InMedia. After all, the largely ethical truth claims of the documentary can partly provide the necessary "transparency that today's supposed fake-news miasma sometimes does not provide", ${ }^{54}$ even when those claims are made in an entertaining fashion. How then can we account for the interaction between the two concepts? 

destroy or further the documentary purview and function. Each author clearly positions their perspective and suggests that there is no moral absolute: each documentarian will find the most adequate way to tackle their subjects and it is up to us, viewers, scholars, citizens, or just plain human beings, to evaluate whether each documentary proposition is valid or not. The five contributions to this issue all reflect on documentaries in context, suggesting that what is considered entertaining by some may not yield the same reaction in other contexts. Music, which can be criticized as distracting spectators from the core of the political intent of a documentary, is tackled head on by Costanza Salvi in her article "Feeling comes first". Music as Entertaining Force in The River, The City, and One Tenth of Our Nation". In the specific context of government film propaganda in the United States of the late 1930s, she shows that the musical accompaniments to political documentaries were far from being the simple aural pleasures their producers meant them to be. On the contrary, documentary musical soundtracks carried much of the political "message" of the films, sometimes contradicting what images and voice over imply. More generally, Salvi's article calls for a better inclusion of sound in documentary studies.

13 Similarly based on the importance of sound, Keith Marley's "Expanded Documentary: The Aesthetics of Pleasure" forcefully suggests that documentaries can engage their viewers in ways more powerful than mere didactic films. Using his own film practice, Marley's main argument is that the formal experiments of the 1920s so-called avantgarde can have a function today. For him, a documentary should not be limited by its usual forms of distribution and should, on the contrary, try to engage potential viewers in such unexpected places as a dancefloor. Pleasing viewers, in a way entertaining them, is meant to lead them to a more intimate engagement with their surroundings. In a more politically explicit framework, Emilie Cheyroux contends that emotions, bare raw guttural reactions to the people seen onscreen, can be used for political purposes. Her article, "Immigrant Rights Documentaries and Engagement: Eliciting Emotion to Counter the Latino Threat Narrative," shows how emotion and pathos can entertain the viewer and, thus, become political forces in the media struggles over the representation of immigrants. Cheyroux claims that humanizing data and mere facts can be quite efficient.

14 The final two articles in this special issue of InMedia deal with the same producer/ distributor of documentaries, the $\mathrm{BBC}$, both focusing on scientific documentaries. In her article "Documenting and Popularising British Nuclear Power: Exploring Science Infotainment," Lucie de Carvalho compares two recent TV documentaries on nuclear energy. She argues with vivid examples that dramatizations have clear political functions. By using clearly identified hosts and by relying on entertaining strategies, the two documentaries she studies tend to frame the nuclear debate within a broad acceptance of nuclear agency. In his article, "The BBC and Disaster Films: From Education to Entertainment," Georges Fournier very clearly argues that entertaining strategies tend to blur the expected purview of BBC documentaries. When the If... series clearly blurs the distinctions between fiction drama and documentary, Peter Watkin's The War Game remains the ultimate example of a film that manages to adequately blend documentary tactics of information with self-conscious reflection on film as entertainment. In addition to the five articles, an in-depth interview introduces the reader to the universe of experimental documentarian Bill Morrison. The filmmaker 
shares his personal definition of documentary film and his take on the use of entertainment in non-fiction films. Covering the subjects of music, aesthetics, emotion, science, education, and filmic experimentation, this issue provides a broad view of the ways in which documentary and entertainment, far from being opposing incompatible terms, come together in a unique fashion producing some of the most innovative cinematic experiences.

\section{BIBLIOGRAPHY}

Austin, Thomas and Wilma de Jong eds. Rethinking Documentary: New Perspectives, New Practices, London and Maidenhead: Open University Press, 2008.

Barnouw Erik. Documentary, A History of Non-Fiction Film. Second revised edition, New York and Oxford: Oxford University Press, 1993.

Baudrillard Jean. Simulacres et simulations, Paris: Editions Galilée, 1981.

Beattie, Keith. Documentary Screens: Nonfiction Film and Television. Basingstoke and New York: Palgrave Macmillan, 2004.

Benson Thomas W. \& Brian J. Snee (eds.). The Rhetoric of the New Political Documentary, Carbondale: Southern Illinois University Press, 2008.

Bruzzi, Stella. New Documentary. Second edition. London and New York: Routledge, 2006.

Corner, John. "Performing the Real: Documentary Diversions", Television \& New Media, Vol. 3 No. 3, August 2002, 257.

Cousins, Mark and Kevin Macdonald eds. Imagining Reality: The Faber Book of Documentary. London: Faber and Faber, 2006.

Debord, Guy. La Société du spectacle, Paris: Gallimard, collection « folio », 1967, 1992.

Delli Carpini, M. and Williams B. "Let us entertain you: Politics in the new media environment." In Bennett L. and Entman R. (Eds.), Mediated politics: Communication in the future of democracy (pp. 160-191). New York: Cambridge University Press. 2001.

Dyer, Richard. Only Entertainment. Second edition. London and New York: Routledge, 2002.

Ellis, Jack C. and Betsy E. McLane. A New History of Documentary Film. London and New York: Continuum Books, 2005.

Gaines,Jane M. and Michael Renov eds. Collective Visible Evidence. London and Minneapolis: University of Minnesota Press, 1999.

Glas, René, Sybille Lammes, Michiel de Lange, Joost Raessens, and Imar de Vries eds. The Playful Citizen: Civic Engagement in a Mediatized Culture. Amsterdam: Amsterdam University Press, 2019.

Goodwin, Andrew, Whannel, Garry. Understanding Television, London: Routledge, 1992.

Grierson, John. On Documentary, London: Faber \& Faber, 1966. 
Hill Annette. “Documentary Modes of Engagement." In AUSTIN T. and DE JONG W. (Eds.), Rethinking Documentary: New Perspectives, New Practices (pp. 217-231). Maidenhead: Open University Press, 2008.

Kelson, Tony. "And now no word from our sponsor, How HBO puts the risk back into television" in LEVERETTE Marc, Brian L. OTT and Cara Louise BUCKLEY (eds.), It's Not TV, Watching HBO in the Post-television Era, New York \& London: Routledge, 2008.

McEnteer, James. Shooting the Truth: The Rise of American Political Documentaries, Westport CO and London: Praeger, 2006.

Menand, Louis. "Nanook and Me: Fahrenheit 9/11 and the Documentary Tradition", The New Yorker, August 9-16 2004, 90-96. , accessed January 12, 2014.

Modleski, Tania ed. Studies in Entertainment: Critical Approaches to Mass Culture. Bloomington and Indianapolis: Indiana University Press, 1986.

Nichols, Bill. Representing Reality. Bloomington, Indiana University Press, 1991.

Nichols, Bill. Introduction to Documentary. Second edition. Bloomington and Indianapolis: Indiana University Press, 2010.

Nichols, Bill. Speaking Truths with Film: Evidence, Ethics, Politics in Documentary. Oakland: University of California Press, 2016.

Niney, François. L'épreuve du réel à l'écran. Essai sur le principe de réalité documentaire. Bruxelles : De Boeck Université, 2002.

Plantinga, Carl. Rhetoric and Representation in Nonfiction Film. Grand Rapids: Chapbook Press, 2010.

Rotha, Paul. Documentary Film. New York: Norton, 1939.

Sayre, Shay and Cynthia King. Entertainment and Society: Influences, Impacts, and Innovations. Second edition. London and New York: Routledge, 2010.

Winston, Brian. Claiming the Real: the Documentary Film Revisited. London: BFI, 1995.

Winston, Brian ed. The Documentary Film Book. London: BFI/Palgrave Macmillan, 2013.

Winston, Brian, Gail Vanstone and Wang Chi. The Act of Documenting: Documentary Film in the $21^{\text {st }}$ Century. London and New York: Bloomsbury, 2017.

\section{ENDNOTES}

1. Paul Rotha, Documentary Film (New York: Norton, 1939), 11.

2. Public Broadcasting Service, a non-profit organization known for producing educational content and showing documentary films.

3. John Grierson is considered by many to be the forefather of the English-language documentary 4. Bill Nichols, Speaking Truths with Film: Evidence, Ethics, Politics in Documentary (Oakland: University of California Press, 2016), 5.

5. Bill Nichols, Representing Reality (Bloomington, Indiana University Press, 1991), 3.

6. See, for examples of his use of the methods of rhetorical analysis, "What Gives Documentary Films a Voice of Their Own?" and "What Documentaries Engaging and Persuasive", respectively chapters 3 and 4 of Bill Nichols, Introduction to Documentary $2^{\text {nd }}$ edition (Bloomington and Indianapolis: Indiana University Press, 2010), 67-119. It has to be recognized that Nichols has tried to nuance his initial theories. See Nichols, Speaking Truth with Film, 41 and 241 note 9. 
7. Carl Plantinga, Rhetoric and Representation in Nonfiction Film (Grand Rapids: Chapbook Press, 2010), 1.

8. John Corner, "Documentary Studies: Dimensions of Transition and Continuity," in Rethinking Documentary: New Perspectives, New Practices, eds. Thomas Austin and Wilma de Jong (Maidenhead and New York: Open University Press, 2008), 25

9. Stella Bruzzi, New Documentary, Second Edition (London and New York: Routledge, 2006), 3.

10. Richard Dyer, Only Entertainment, Second Edition (London and New York: Routledge, 2002), 19.

11. Ibid, 1.

12. Tania Modleski, "Introduction," in Studies in Entertainment: Critical Approaches to Mass Culture, ed. Tania Modleski (Bloomington and Indianapolis: Indiana University Press, 1986), ix-xix.

13. Richard Dyer, Only Entertainment, 1.

14. Tania Modleski, "Introduction", xiii.

15. Greg W. Bevan, "Dramatising the Mundane: The Working Man Hero in John Grierson's Drifters," Montage Film Reviews, 2008. http://www.montagefilmreviews.com/reviews/d/ RS_Drifters(1929).html <accessed on March 6, 2019>.

16. Mark Cousins and Kevin Macdonald, eds, Imagining Reality: The Faber Book of Documentary (London: Faber and Faber, 2006), 93.

17. Brian Winston, Claiming the Real: the Documentary Film Revisited (London: BFI, 1995), 254.

18. Ibid, 255.

19. Sonya Michel, "Feminism, Film, and Public History," in Issues of Feminist Film Criticism, ed. Patricia Erens (Bloomington: Indiana University Press, 1990), 238.

20. Richard Dyer, Only Entertainment, 3.

21. Peter Wintonick, "New Platforms for Docmedia: 'Varient of a Manifesto"', The Documentary Film Book, ed. Brian Winston (London: BFI/Palgrave Macmillan, 2013), 376.

22. Brian Winston, Gail Vanstone and Wang Chi, The Act of Documenting: Documentary Film in the $21^{\text {st }}$ Century (London and New York: Bloomsbury, 2017).

23. Richard Dyer, Only Entertainment, 1.

24. Ibid, 177.

25. Shay Sayre and Cynthia King, Entertainment and Society: Influences, Impacts, and Innovations, 2nd edition (London and New York: Routledge, 2010), 5.

26. Matthew Jacobs, "Stranger Than Fiction: How Documentaries Invaded the Zeitgeist", The Huffington Post, July 13, 2018. https://www.huffpost.com/entry/how-documentaries-invaded-thezeitgeist_n_5b3fa73ce4b09e4a8b2cb805 <accessed on May 21, 2019>.

27. Mandalit Del Barco, "The Documentary is In - And Enjoying an 'Undeniable Golden Age", heard on "All Things Considered", National Public Radio, February 19, 2019, https:// www.npr.org/2019/02/19/696036323/the-documentary-is-in-and-enjoying-an-undeniablegolden-age, <accessed on May 15 ,2009>.

28. Jack C. Ellis and Betsy E. McLane, A New History of Documentary Film (London and New York: Continuum Books, 2005), 179.

29. Betsy McLane, "The Golden Age: IDA Grows Along With the Documentary", Documentary Magazine, March 2002, https://www.documentary.org/feature/golden-age-ida-grows-alongdocumentary <accessed on May 15, 2009>.

30. Chuck Braveman, "Is the New Golden Age of Documentary Over?", Documentary Magazine, N/ D, https://www.documentary.org/feature/new-golden-age-documentary-almost-over <accessed on May 15, 2009>.

31. Bill Nichols, Introduction to Documentary $2^{\text {nd }}$ edition (Bloomington and Indianapolis: Indiana University Press, 2010), 1.

32. François Niney, L'épreuve du réel à l'écran. Essai sur le principe de réalité documentaire (Bruxelles: De Boeck Université, 2002), 319.

33. Representing Reality, 77. 
34. In 1989 Roger \& Me was the highest grossing documentary film of the year. In 2019 it is still ranked at number 41 on the list of all time highest grossing documentary films. Box Office Mojo, https://www.boxofficemojo.com/genres/chart/?

id=documentary.htm\&sort=rank\&order=ASC\&p=.htm <accessed on June 6th 2019>.

35. Paul Arthur, "'Everything is Personal': Michael Moore and the Documentary Essay," in Michael Moore, Filmmaker, Newsmaker, Cultural Icon, ed. Matthew Bernstein (Ann Arbor: University of Michigan Press, 2010), 105.

36. Michael Moore, "13 Rules for Making Documentary Films," Huffington Post, November 17, 2014. https://www.huffingtonpost.com/michael-moore/13-rules-for-makingdocum_b_5834954.html <accessed on November 20, 2018>.

37. Fanning Hearon, "The Motion-Picture Program and Policy of the United States Government." The Journal of Educational Sociology 12, no. 3 (1938), 151.

https://www.jstor.org/stable/2261882?seq=5\#metadata_info_tab_contents <accessed on November 20, 2018>.

38. Baillie, Russell (14 November 2018). "How Kiwi Anthony McCarten wrote the Queen movie Bohemian Rhapsody". Noted. BAUER MEDIA PTY LTD. https://www.noted.co.nz/ culture/movies/bohemian-rhapsody-kiwi-anthony-mccarten-wrote-queen-movie/ $<$ accessed on July $21,2019>$.

39. Ibid.

40. Bill Nichols, Introduction to Documentary, 16.

41. Michael Renov, "Documentary Horizons: An Afterword," in Collective Visible Evidence, eds. Jane

M. Gaines and Michael Renov (London and Minneapolis: University of Minnesota Press, 1999), 321.

42. Elizabeth Cowie, "The Spectacle of Actuality," in Collective Visible Evidence, eds. Jane M. Gaines and Michael Renov (London and Minneapolis: University of Minnesota Press, 1999), 19.

43. Annette Hill, "Documentary Modes of Engagement," Rethinking Documentary: New Perspectives, New Practices, eds. Thomas Austin and Wilma de Jong (London and Maidenhead: Open University Press, 2008), 217-231.

44. Craig Hight, "Beyond Sobriety: Documentary Diversions," The Documentary Film Book, ed. Brian Winston (London: BFI/Palgrave Macmillan, 2013), 199.

45. Ibid, 201-203.

46. John Corner, "Performing the Real: Documentary Diversions", Television \& New Media, Vol. 3 No. 3, August 2002, 257.

47. Ibid, 260.

48. Keith Beattie, Documentary Screens: Nonfiction Film and Television (Basingstoke and New York: Palgrave Macmillan, 2004), 25.

49. Ibid, 25.

50. Richard Dyer, Only Entertainment, 177.

51. William Uricchio, "Re-thinking the Social Documentary," The Playful Citizen: Civic Engagement in a Mediatized Culture, eds. René Glas, Sybille Lammes, Michiel de Lange, Joost Raessens, Imar de Vries (Amsterdam: Amsterdam University Press, 2019), 73-74.

52. The documentary utopian potentials are described by Brian Winston, Gail Vanstone and Wang Chi in the first part of The Act of Documenting: Documentary Film in the $21^{\text {st }}$ Century. For the authors, the limiting constraints of the past are due to "the privileged white male documentarist from the global north". Brian Winston, Gail Vanstone and Wang Chi, The Act of Documenting, 9.

53. The deepfake phenomenon is only the latest example in a long list of technologically induced distrusts in the reality of photographic images.

54. Matthew Jacobs, "Stranger Than Fiction". 


\section{AUTHORS}

\section{DAVID LIPSON}

David Lipson is an associate professor of English at The University of Strasbourg. He holds a Ph.D. in American Studies and Civilization at the Université Sorbonne Nouvelle - Paris III. His research interests are documentary films, infotainment, politainment, political satire and media studies, as well as contemporary American history.

\section{ZACHARY BAQUÉ}

Zachary Baqué is an Associate Professor at the University of Toulouse - Jean Jaurès, where he teaches American and Film Studies in the English Department. He has published several articles on David Lynch and American documentary films. His research now focuses on the documentaries produced by and for the US federal government from the 1930s to the 1960s. 